\title{
Narrativas da trajetória escolar de um formador de professor: \\ memória, história e formação
}

BATISTA NETO, José ${ }^{1}$

\section{RESUMO}

A narrativa da trajetória escolar de formador de professores é trazida à luz como pretexto para discussão sobre a relevância de material biográfico em processos formativos. Práticas relacionadas ao método biográfico no cenário da escola de educação básica são aqui exploradas com a finalidade de evidenciar seu potencial formativo. A contextualização foi um recurso metodológico observado, tendo de seu uso resultado um texto recheado de notas históricas. A narrativa de trajetória escolar e do contexto de produção compõe aqui um memorial, entendido como um olhar lançado sobre a história de vida de um docente que toma sua vida como objeto e, de suas experiências, faz história. É uma história de si, uma autobiografia, pela qual nos fazemos historiadores de nós mesmos. A narrativa deslindou traços da escola, da formação de professores e da prática pedagógica, de modo a fazer compreender a participação da dimensão biográfica no processo formativo de professor.

Trajetória escolar. Biografia. Formação de professor.

\section{Narratives of the school career of a teacher trainer: memory, history and formation}

\section{ABSTRACT}

The narrative of the school trajectory of teacher educator is brought to light as a pretext for discussion about the relevance of biographical material in formative processes. Practices related to the biographical method in the scenario of the elementary school are explored here in order to highlight its formative potential. Contextualization was an observed methodological resource, and its use resulted in a text full of historical notes. The narrative of the school trajectory and the context of production composes here a memorial, understood as a look at the life story of a teacher who takes his life as an object and, from his experiences, makes history. It is a story of itself, an autobiography, by which we make ourselves historians of ourselves. The narrative unraveled traces of the school,

\footnotetext{
${ }^{1}$ Doutor em Ciências da Educação e Professor Titular do Departamento de Métodos e Técnicas de Ensino, do Programa de Pós-graduação em Educação da Universidade Federal de Pernambuco. Professor na graduação de História da Universidade Federal de Pernambuco e membro do centro Paulo Freire estudos e pesquisas. E-mail: netojose31@gmail.com. Lattes: http://lattes.cnpq.br/4598908452423232. ORCID: https://orcid.org/0000-0001-9780-4264.
}

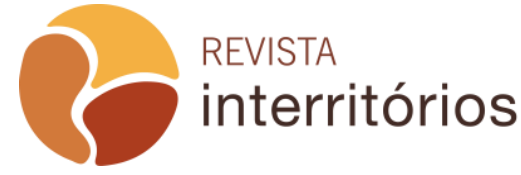


teacher training and pedagogical practice, in order to make the participation of the biographical dimension in the teacher training process easier to understand.

School trajectory. Biography. Teacher training.

\section{Narrative della carriera scolastica di un insegnante di maestri: memoria, storia e formazione}

\section{RIASSUNTO}

la narrazione della traiettoria scolastica dell'insegnante viene messa in luce come pretesto per la discussione sulla rilevanza del materiale biografico nei processi formativi. Le pratiche del metodo biografico nello scenario della scuola elementare sono esplorate qui al fine di evidenziarne il potenziale formativo. La contestualizzazione era una risorsa metodologica osservata e il suo uso ha prodotto un testo pieno di note storiche. La narrazione della traiettoria della scuola e il contesto della produzione compongono qui un memoriale, inteso come uno sguardo alla storia di un insegnante che prende la sua propria vita come oggetto e, dalle sue esperienze, fa la storia. È una storia di se stessa, un'autobiografia, con la quale ci rendiamo storici di noi stessi. La narrazione ha svelato le tracce della scuola, della formazione degli insegnanti e della pratica pedagogica, al fine di facilitare la comprensione della partecipazione della dimensione biografica al processo di formazione degli insegnanti.

Traiettoria della scuola. Biografia. Formazione degli insegnanti.

\section{Narrativas de la carrera escolar de un formador de docentes: memoria, historia y formación}

\section{RESUMEN}

La narrativa de la trayectoria escolar del formador de docentes sale a la luz como pretexto para la discusión sobre la relevancia del material biográfico en los procesos formativos. Aquí se exploran prácticas relacionadas con el método biográfico en el escenario de la escuela primaria para resaltar su potencial formativo. La contextualización fue un recurso metodológico observado, y su uso resultó en un texto lleno de notas históricas. La narrativa de la trayectoria escolar y el contexto de producción compone aquí un memorial, entendido como una mirada a la historia de vida de un maestro que toma su vida como un objeto y, desde sus experiencias, hace historia. Es una historia en sí misma, una autobiografía, por la cual nos hacemos historiadores de nosotros mismos. La narración desvela las huellas de la escuela, la formación del profesorado y la práctica pedagógica, a fin de facilitar la comprensión de la participación de la dimensión biográfica en el proceso de formación del profesorado.

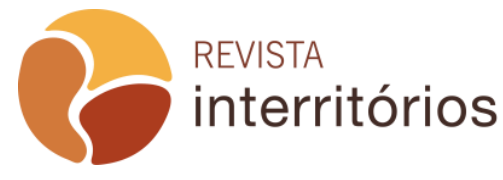


Trayectoria escolar. Biografía. Formación del profesorado.

\section{INTRODUÇÃO}

A intensificação de trocas acadêmicas tem favorecido a circulação de pesquisadores sociais entre diversos centros universitários do país e do exterior, - que tem acarretado a incorporação de novas problemáticas, novas abordagens, novos objetos e novas metodologias. Problemáticas relativas à subjetividade, ao imaginário social, às representações sociais e à identidade sócio profissional fizeram sua aparição e instalaram-se em definitivo no cenário das pesquisas sociais. No que concerne à metodologia, é cada vez mais frequente a utilização, não sem riscos, de técnicas de pesquisa qualitativa baseadas na relação aprofundada com um pequeno número de atores sociais. Como adverte Ana Sofia António (2004, p. 99), a história de vida, a biografia e a entrevista em profundidade são exemplos dessa tendência e têm se constituído em instrumentos privilegiados de análise da realidade para a pesquisa social em geral, e, em particular, das pesquisas históricas e sociológicas.

O mesmo fenômeno pode ser observado em relação à pesquisa educacional (GATTI, 1987, ALVES-MAZZOTTI, 2001). Investigações de abordagem qualitativa em vários de seus domínios, servindo-se de metodologias de mesmo corte, começam a aparecer a partir do final dos anos 1980, visando dar conta dos atores sociais e suas práticas educativas. Desde então, "observase um vivo interesse pela narrativa que elaboram os atores em relação à vida cotidiana, ao desenvolvimento pessoal, às relações familiares, à trajetória escolar, à carreira profissional e aos meios social e cultural em que o indivíduo se insere" (ANTÓNIO, 2004, p. 100). A narrativa fornecida registra não somente informações objetivas (tempo, espaço, sujeitos, cenário, enredo, desfecho) sobre acontecimentos como também o significado que os atores a eles atribuem, abrindo espaço para significados antes ignorados pela pesquisa.

A renovação teórico-metodológica atinge também o campo da formação. Técnicas do método biográfico passam a ser adotadas em atividades de formação inicial e continuada de professores. A emergência de práticas relacionadas com o método biográfico no cenário da formação de professores parece ser uma evidência do reconhecimento do potencial e valor social do material biográfico em processos formativos.

Interessa aqui a abordagem biográfica enquanto um instrumento de pesquisa educacional e de formação docente. Quero começar refletindo sobre o lugar de onde falo. Faço essa escolha de forma estratégica, porque ela me ajuda a dizer da natureza do texto que forneci ao leitor. O texto é literalmente uma 
escrita ex post de minha trajetória de formação, dimensão de minha história de vida $^{2}$.

Não a produzi a escrita a "sangue quente", mas com distanciamento no tempo e na baixa fervura dos sentimentos e o dos afetos/desafetos refletidos. Ao escrever a posteriori, pude juntar pedaços, selecionar fragmentos da existência e compor uma "colagem" de objetos de distintas texturas existenciais.

A escrita com distanciamento não me poupou do cuidado com o não cometimento de anacronismos, esse pecado original dos historiadores. Não pude me livrar, no entanto, de escrever sobre o passado com os pés fincados no presente, no dizer de Liliana Jacott e Mario Carretero (1998). Jacott e Carretero sinalizam, com esta máxima, outra coisa senão a ação de presentificação do passado, ainda que tenha me esforçado para restituir ao leitor as cores, os cheiros, os sabores e saberes de tempos vividos. Tempos transversos, tempos atravessados por mim e em mim. Em mim, residia o desejo de não atravessar o ritmo e entregar ao leitor um texto redondo. Sobretudo, não quis contar os casos como os casos foram, como consagrou um político pernambucano em suas memórias. Afinal, essa relação entre testemunho de si, por si, e a verdade vem a se constituir em objeto contaminado. É suja de quereres e não quereres, do desejo de falar e calar, de pronunciar e silenciar, intencionalmente. Não fugi a isso. Fui também isso.

O texto assume, nitidamente, um assento memorialístico. O memorial, do latim memoriale, remete àquilo que ajuda a memória. É um gênero textual literário por meio do qual o autor evoca fatos a que tenha assistido ou em que tenha tomado parte. O termo alude ainda a diversos significados $\mathrm{O}$ termo é, portanto, polissêmico e porta representações que remetem a objetos materiais ou imateriais, concretos ou simbólicos, mas com uma finalidade precípua, a de construir a memória visando os diversos usos que a ela se pode dar, dentre os quais elaborar significados para gerar sentidos.

$\mathrm{Na}$ escrita deste texto, retive o significado de um texto o qual terá como objeto eventos da vida escolar ou a ela conexa que constituem a trajetória formativa, prévia à trajetória profissional. Estou me referindo ao acontecido ao longo do que, hoje, denominamos de educação básica.

Como disse, trata-se de um texto que envolve a memória, o que a estimula, mas também o que é por ela estimulado, sendo, neste caso preciso, memória escolar. O memorial assume aqui o significado de ação de pensar sobre a trajetória de formação, trazendo de arrasto características que lhes são peculiares, tais como: ser um texto descritivo em que se expõem eventos, impressões pessoais, ideias, críticas e reflexões. Isso não quer dizer que com

\footnotetext{
${ }^{2} \mathrm{O}$ texto assume caráter de memória da vida escolar, tendo sido intencionalmente escrito na primeira pessoa do singular.
}

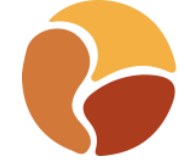


ele não se busque problematizar, que não se levantem questões sobre os assuntos tratados, atividade marcada pela opinião do autor, que, geralmente, ao fim e ao cabo, pode resultar em conclusões originais. São de se esperar de um memorial interpretação e análise mais profunda sobre um tema.

O memorial é, assim, um olhar lançado sobre a história de vida de um docente que toma sua vida como objeto e, de suas experiências, faz história. É uma história de si, uma autobiografia, pela qual nos fazemos historiadores de nós mesmos. Esse modo de tecer a narrativa ultrapassa os limites da história objetiva, aquela cuja feitura é baseada em documentos oficiais preservados em arquivos. É uma leitura subjetiva de eventos inscritos num tempo-espaço social, histórico, político, cultural e educacional. Essa leitura afirma possibilidades, dentre as quais se destaca a do olhar divergente, prenúncio da diversidade de interpretações, em cuja origem está o lugar de quem olha, de quem interpreta. Sua utilização resultaria, de algum modo, do repúdio ao autoritarismo da história única, da história oficial.

Ao afirmar a diversidade de interpretações, o sentido do memorial distancia-se de certo entendimento do que seja memória, prática social cuja finalidade seria, no dizer de Montenegro (2018), "[...] a tentativa de eternizar um único significado do passado", pois, constitui-se enquanto "[...] práticas e discursos a estabelecerem significados únicos sobre o passado histórico".

O memorial seria, assim, um texto cujo objeto é histórico, portanto ele comporta conteúdos que o constituem enquanto uma reescrita de acontecimentos do passado, inscritos, nesse caso, na trajetória formativa de um docente universitário. Para tal operação intelectual, foi necessário cavoucar nas experiências que habitam os lugares da memória de um tempo passado. Quando se escreve um memorial, dá-se existência a memórias sobre o que foi, donde ainda se está. É assim um passado presentificado (BARBOSA, 2003).

Fui aqui, ao mesmo tempo, narrador e ouvinte de mim mesmo, de minhas práticas, que ganham significado quando embebidas em seu contexto social, político e cultural. Esse exercício possibilitou-me passar da "pura" memória para a narração de feitos, sem me deixar sucumbir à solidão nem à solitude (SANTOS, 1998) e esforçando-me para dizer como percebo minha vida e as trajetórias que ela descreveu em distintos contextos que as condicionaram. Assim, pude, no reencontro com a ação lembrada, produzi falas que me provocaram conforto e desconforto. O tempo de lembrar produziu em mim sentires diversos, não sendo uma espécie de convescote em "terras de mim mesmo", mas traduzindo-se em tempo de estudar, em tempo de trabalhar sobre o ser e estar na Educação Básica. 
O duplo exercício de buscar em mim mesmo e retornar ao contexto mais amplo, para nele encontrar sentidos, denota o tanto de subjetivo e de objetivo, de individual e de social que habita o ato de lembrar.

Nessa linha argumentativa, Chauí (2003, p. 31) adverte que

[...] o modo de lembrar é individual tanto quanto social: o grupo transmite, retém e reforça as lembranças, mas o recordador, ao trabalhá-las, vai paulatinamente individualizando a memória comunitária e, no que lembra e no como lembra, faz com que fique lendário do trabalho e da festa, do evento político e do fato insólito, mas também porque repercute no modo de lembrar.

Ao dizer do ato de lembrar, Chauí destaca seu caráter relacional, composicional, e assim narrar as lembranças não é se enredar no lugar do indivíduo solitário, mas no lugar de quem intercambia experiências e, ao fazê-lo, extrai conteúdos cujos significados constroem-se numa relação entre Eu e Outro. Nesse sentido, vai-se ao encontro das teses benjaminianas sobre o narrador. Para Walter Benjamin (1987, p. 198), o "[...] narrador conta o que ele extrai da experiência - sua própria ou aquela contada por outros. E, de volta, ele a torna experiência daqueles que ouvem a sua história". Isso porque, a "[...] experiência que passa de pessoa a pessoa é a fonte a que recorreram todos os narradores" (BENJAMIN, 1987, p. 198).

Assim, fui instado a fazer-me narrador, a produzir uma narrativa. Nesse sentido, narrar é trabalhar. Um trabalho por vezes sofrido, por vezes prazeroso, por vezes ainda mistura de tudo num só enredo. Ninguém passa isento da narrativa de sua própria experiência. Aquela mesma ausência de isenção a que se referiu Freire ao analisar a constituição de um leitor, na Introdução de uma de suas mais conhecidas obras, Pedagogia do Oprimido (1983).

Como disse, fui instado a fazer-me narrador de minha própria vida, tomada como objeto (BOURDIEU, 1986). Restituí ao leitor minha história de vida, organizada em uma trajetória. A escrita da história de vida é ato que requer o acesso, a interpelação da memória, do espaço, do tempo em que o vivido se encontra "depositado", hospedado. A escrita da história de vida, enquanto ato recriador, desafia seu escritor à compreensão do vivido depositado, que não se compõe de matéria estática, imóvel, imobilizada. A escrita da história de vida é tarefa exigente e resulta de transação entre o sujeito "historiador" e a memória, mediadora do encontro entre o escritor e o objeto de sua escrita. É uma composição entre o escritor e o texto que produz (FREIRE, 1983), de que se exige superação de medos, de cautelas, de lembranças reprimidas, de culpas, para que "zonas" da memória possam ser acessadas, possam manifestar-se e dizer, de forma intencional e autorizada, o antes não dito, aí incluído o indizível. 
O conflito entre o dizer e o não dizer, a tensão que consome o narrador bloqueia ou libera conteúdos, ou faz fluir, enfim, filtra o que está autorizado a vir à luz. Dessa tensão ninguém se livra. A história de vida é e será sempre o que o sujeito autorizou, explicitando que ele está no comando do processo narrativo. Os significados liberados são criação do narrador, entregues à ação leitora forjada por sujeitos ante o texto, que o recriarão, conforme seus meios de bordo.

A justo título, De Gaulejac (1988) admite que a memória funciona por meio de um jogo de duas forças psíquicas contraditórias: a amnésia e a lembrança. Essas duas forças agem em sentido oposto, o que faz da memória "matéria" manipulável. O indivíduo, que a isso recorre para contar sua história, opera triagem, uma seleção de material simbólico que se constituirá em lembrança ou esquecimento.

O texto-memorial está composto por três seções, A primeira se compõe de uma introdução na qual faço uma discussão sobre a natureza do texto e as conexões que guarda com as temáticas da memória e da história. Explicito o significado da narrativa que toma um segmento da história de vida como objeto, organizada em uma trajetória escolar. Em seguida, a narrativa se debruça sobre a trajetória escolar propriamente dita, com destaque para eventos ocorridos na educação básica. Restituo ao leitor as diversas experiências consideradas relevantes em meu percurso de estudante dos cursos primário e secundário, no dizer da época. Como sustenta Benjamin (1987), por meio de uma operação intelectual de análise, extraio os significados que emanam das experiências, sem que me toque o interesse por identificar um "sentido da vida" que possa suscitar o percurso vivido. Na terceira seção, o texto é finalizado com algumas considerações à guisa de síntese e reflexão final.

\section{Trajetória escolar de um formador de professores}

Há uma íntima relação entre o que escola fez comigo e a formação do meu pensamento sobre a escola.

José Carlos Libâneo, 2009.

Trato, nesta seção, da escolarização desde o ingresso na Educação Básica, que à época denominava-se de pré-primário, até a conclusão do curso secundário. O contexto social mais amplo, as políticas educacionais e a formação dos professores atuantes em cada etapa da Educação Básica não são perdidas de vista. 
Iniciei minha educação formal aos seis anos de idade, com o ingresso em uma classe pré-primária de uma escola primária. Com essa mesma idade, meus três filhos já contavam com cinco anos de Educação Infantil, o que incluiu uma passagem pelo berçário, pelo maternal e pela pré-escola. Se hoje essa etapa da Educação Básica ainda ostenta um déficit no atendimento às crianças de zero a seis $a_{n o s}^{3}$, no início dos anos 1960, período ao qual estou me referindo, esse déficit era ainda maior. Na verdade, iniciei minha escolarização no ensino préprimário, que era composto de escolas maternais e jardins de infância, segundo a estrutura do ensino estabelecida pela Lei de Diretrizes e Bases da Educação Nacional (LDB) de 1961, Lei o $4.024^{4}$ (LIMA e SILVA JÚNIOR, 2016).

A explicação para que um ingresso "tardio" na escola só se fizesse a partir do jardim de infância pode se obter com o recurso a outra hipótese. A associação entre 0 efeito da relativa ascensão na renda das famílias da classe trabalhadora, obtida no período pós-governo Juscelino Kubitschek (1956-1961), e um certo tradicionalismo no arranjo familiar pode, talvez, explicar o fato de uma escolarização só iniciada aos seis anos. Até aquela idade, estive sob os cuidados de minha mãe, que não havia feito, nem veio a fazer depois, ingresso no mercado de trabalho. Portanto, minha família não se apresentava como demandante de vagas em creche. Assim, naqueles anos iniciais da década de 1960, as duas razões que provocaram a emergência de políticas de atendimento a crianças de zero a três anos no Brasil não afetaram minha família. Segundo Andrade (2010), as creches no Brasil surgiram para minimizar os problemas sociais decorrentes do estado de miséria de mulheres e crianças. A esse fator pode ser acrescido, para regiões industrializadas do país, que a demanda por

\footnotetext{
${ }^{3}$ Considerando que todo brasileiro/a têm o direito ao acesso à escola, assegurado pela Constituição Federal de 1988, a Meta 1 do Plano Nacional de Educação (PNE) 2014-2024 estabelece que $50 \%$ das crianças de 0 a 3 anos de idade tenham acesso à creche e a universalização da pré-escola para crianças de 4 a 5 anos. Segundo dados da PNAD/IBGE, desde 2001, observa-se um crescimento constante na porcentagem dessas crianças na Educação Infantil. Em 2015, o atendimento atinge a marca de 30,4\% para o primeiro corte etário ( 0 a 3 anos), o que significa que, em números absolutos, mais de 3,5 milhões de crianças estão em creches. Para o intervalo de idade dos que estão na pré-escola, o atendimento atingiu a marca de $90,5 \%$, correspondendo, em números absolutos, a aproximadamente 4,9 milhões das crianças brasileiras. Apesar do crescimento em termos percentuais, a Meta 1 do PNE, que estipula a universalização do acesso para a Educação Infantil, provavelmente não será cumprida. A aprovação da Emenda Constitucional no 95, proposta e sancionada pelo governo Temer, que congela os gastos primários no orçamento da União por 20 anos, bem como os cortes nos orçamentos do MEC, estes feitos pelo governo Bolsonaro, não só retardarão ainda mais o alcance da Meta como poderão causar a diminuição dos níveis de atendimento já atingidos. Os dados aqui referidos foram extraídos do Censo Escolar 2016. Notas Estatísticas. Brasília: MEC/INEP, fevereiro de 2017. Disponível em: http://portal.mec.gov.br/docman/fevereiro-2017-pdf/59931-app-censo-escolar-da-educacaobasica-2016-pdf-1/file. Acessado em: 30/1/2018.

${ }^{4}$ Segundo o Art. 23, a "[...] educação pré-primária destina-se aos menores de até sete anos, e será ministrada em escolas maternais ou jardins-de-infância".
}

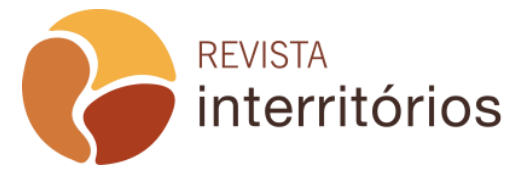


creches decorria da necessidade de atendimento a crianças cujas mães haviam sido recrutadas como mão de obra para as fábricas. Como minha família não se encontrava nem numa situação nem na outra, creio que fui ficando entre os cuidados, a educação e as brincadeiras domésticas até que desembarquei no Instituto Domingos Sávio, em Campina Grande, cidade do Agreste paraibano.

\section{Foto 1: Prédio do antigo Instituto Domingos Sávio}

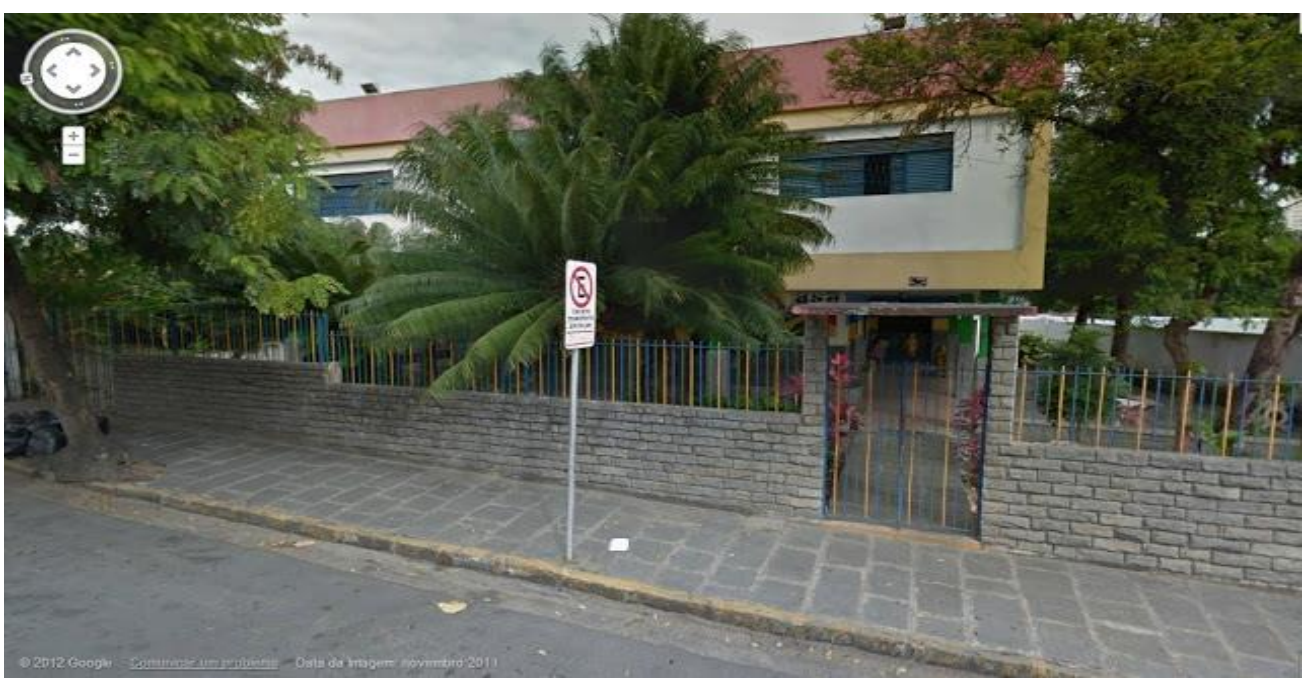

Fonte: http://cgretalhos.blogspot.com/2012/10/reminiscencias-instituto-domingossavio.html\#.XZTIgUZKjIV

O Instituto Domingos Sávio era uma escola privada confessional, mantida pelo convento de São Francisco, no bairro da Conceição. Criado pela educadora Terezinha Leite, atendia ao ensino primário e à educação pré-primária. Ingressei no momento mesmo em que a escola construía novas instalações, em prédio próprio, que a tornou um estabelecimento dotado de salas adequadas, auditório e um pátio de recreação amplo. Lembro-me bem do funcionamento de minha turma de pré-primário, durante a fase final da construção, em um espaço improvisado (a garagem de uma residência ao lado da escola). A turma do primeiro ano primário que frequentei já veio a funcionar no novo prédio, em sala arejada, bem iluminada e equipada. 
Foto 2: Professores e alunos/as do curso primário do Domingos Sávio

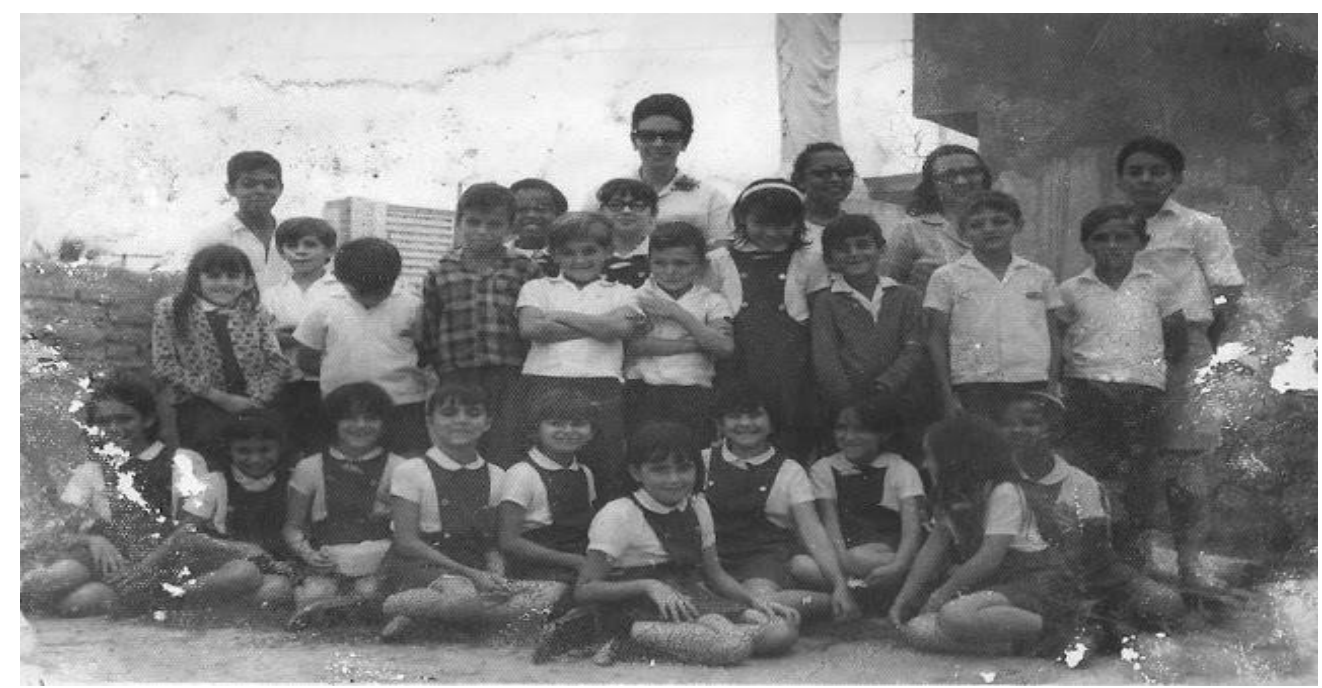

Fonte: http://cgretalhos.blogspot.com/2012/10/reminiscencias-instituto-domingossavio.html\#.XZTIgUZKjIV

A confessionalidade da educação se revelava no Domingos Sávio não somente na tutela administrativa, mas, sobretudo, em sua prática pedagógica escolar. Encontros para prelações com os frades franciscanos (OFM) no adro da igreja do convento de São Francisco e atividades culturais, no auditório, nas quais temas cívicos e religiosos, em datas comemorativas, conferiam à minha educação um halo católico romano do qual jamais me esqueci. Havia sempre a presença de frades franciscanos alemães - na visão de uma criança de sete anos, gigantes de pele branca, em suas vestes marrons, amarradas por torçais repletos de nós e calçando grandes alpercatas - e suas frases em um português indecifrável de quem mal dominava o vernáculo. Uma imagem humana contrastante com aquele espaço social, plantado no Agreste paraibano, sobre o Planalto da Borborema.

A confessionalidade é um traço da educação brasileira e, como se sabe, remonta ao período colonial, quando, já nas primeiras décadas do século XVI (1549), chegaram os padres da Companhia de Jesus, logo secundados por franciscanos (1585) e beneditinos. Primeiro em Pernambuco e São Vicente, para depois se instalarem em outras capitanias do Nordeste brasileiro, os religiosos franciscanos foram, como eles se reivindicam, "[...] os operários da primeira hora na vinha inculta do Senhor no vasto Brasil", aqueles que ofereceram "[...] as primícias do sangue a fertilizar a terra para germinar cristãos e que, outrossim, foram, durante decênios, os únicos religiosos a espalhar a semente do Evangelho" (RÖWER, 1941). Portanto, contribuíram decisivamente, com outros sujeitos históricos, para com a educação colonial no chamado período heroico (entre a primeira metade do século XVI e o final deste século), nas palavras de Saviani (2011). Colaboraram assim, por meio da aculturação das populações

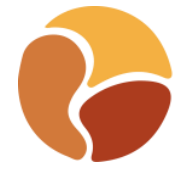


nativas, na qual a catequese estabelecia estreita simbiose com a educação, para a dominação do estado metropolitano europeu nas terras brasileiras. A tríade colonização, ela mesma, catequese e educação - desempenhou papel fundamental para que a dominação colonial se impusesse e fosse exitosa.

A educação a que fui submetido no Domingos Sávio nada tinha dos traços característicos do tal período heroico, mas tinha tudo a ver com as permanências, de longa duração, da segunda fase da educação brasileira promovida pelo estado metropolitano, aquela na qual a organização e consolidação da educação foi pautada pelo Ratio Studiorum ${ }^{5}$.

A escolaridade em terras do Agreste paraibano foi interrompida porque a família voltou a migrar para o Recife, em razão dos compromissos de trabalho de meu pai. Voltamos ao Recife e, após a instalação, fui matriculado em uma escola próxima à minha casa, Educandário Duque de Caxias. O Duque de Caxias já era do conhecimento de meus pais, pois ali já haviam passado meus irmãos mais velhos, antes de migrarmos para a Paraíba. Sabia-se de sua fama de escola exigente, porque "conteudista", para usar o jargão dos iniciados na pedagogia. Era uma escola que "puxava", que "puxava muito" pelos alunos. Desfrutava, portanto, do respeito das famílias do bairro em que morava. A representação de escola de boa reputação passava, naquele momento e no meu grupo social de pertencimento, por esses critérios.

O Educandário Duque de Caxias era uma escola privada de poucos alunos de um bairro popular periférico do Recife, mas de um rigor disciplinar de dar orgulho ao nome de seu patrono. De modo que, além de estudar sob um rígido regime disciplinar, fui submetido, ao longo do curso primário, a uma prática pedagógica centrada em conteúdos disciplinares cujos saberes e habilidades me conferiram capacidade para escrever com o uso do dialeto de prestígio sem grandes erros ortográficos, "armar e efetuar" com as quatro operações após exercícios repetitivos, mas, também, memorizar estados e capitais, definir acidentes geográficos, nomear o relevo, o clima e a hidrografia das regiões brasileiras, assim como descrever fenômenos da natureza, nomear os planetas do sistema solar, definir os principais termos que designavam os corpos celestes e conhecer a singularidade de fatos históricos do Brasil e sua entrada no mundo

\footnotetext{
${ }^{5}$ Para estabelecer essa periodização da educação brasileira, apoio-me em Saviani (2011). Segundo essa periodização, um primeiro período caracteriza-se pelo "monopólio da vertente religiosa da pedagogia tradicional" subdividida em duas fases, o chamado período heroico e a da institucionalização da pedagogia jesuítica, sistematizada pelo Ratio Studiorum; um segundo período compreende parte do período final da colonização portuguesa, todo o período imperial e a república velha, portanto trata-se de um período bastante heterogêneo, marcado, de início, pelas ideias da reforma pombalina do chamado despotismo esclarecido e pelo desenvolvimento de uma pedagogia leiga, orientada por teses liberais e positivistas nos anos 1930; o domínio das ideias da pedagogia nova até a sua crise, no final dos anos 1960, marca o terceiro período; e um quarto período caracteriza-se pela ascensão do "produtivismo" pedagógico e suas variantes, e por ensaios críticos e contra hegemônicos.
}

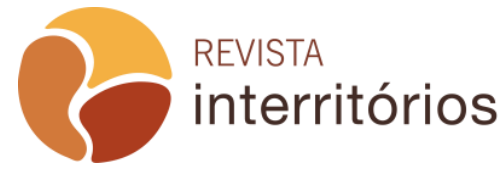


colonial português. A experiência escolar no curso primário não havia embotado minha inteligência, mas dela resultou um aluno mediano, dotado de competências suficientes para obter êxito em processos seletivos para o ingresso no curso ginasial ${ }^{6}$, a exemplo dos que me submeti, em 1967, no Ginásio de Aplicação e no Colégio Militar do Recife.

Para alguém originário de família numerosa e pertencente aos estratos sociais menos favorecidos, a escola pública era a alternativa prioritária de escolarização. Dois irmãos mais velhos já haviam passado pelas bancas do Ginásio de Aplicação (anos mais tarde, dois outros, um irmão e uma irmã, viriam se somar). A condição de pouco escolarizados de meu pai e minha mãe foi necessária, talvez, para que ele e ela aspirassem a uma escolaridade longa para seus filhos e filhas, o que incluía como meta dotar todos, sem exceção, de um diploma de curso superior. Assim, por detrás de estudos alongados que terminei por realizar, estiveram um pai e uma mãe presentes e estimuladores, com cobranças, punições e muitos afagos ${ }^{7}$.

Urge destacar três características que marcam as primeiras experiências escolares. A trajetória escolar dos anos iniciais de escolarização se faz em estabelecimentos do setor privado, confessional e particular. $\mathrm{Na}$ verdade, confessional católica e particular de natureza familiar. Dois traços comuns à prática pedagógica de ambos os estabelecimentos: o ensino tradicional "conteudista" que associava a instrução e à formação moral e um currículo "disciplinado", portanto, organizado por disciplinas dispostas no tempo didático que expressava claramente a desigualdade epistêmica entre as áreas do conhecimento. Todo o trecho da trajetória, de cinco anos de duração, se fez com professoras, com formação de normalista, portanto, para o magistério em nível médio.

\footnotetext{
${ }^{6} \mathrm{Fiz}$ a passagem para o primeiro ciclo do secundário (curso ginasial) quando o exame de admissão ao ginásio dava sinais de declínio. O exame foi introduzido na legislação educacional brasileira através do Decreto $\mathrm{n}^{\circ} 4.468$, de $1^{\circ}$ de fevereiro de 1870 , que o instituiu como condição para o ingresso no Colégio Pedro II (AKSENEN e MIGUEL, 2014). Posteriormente, tornou-se obrigatório nas escolas públicas de todo o Brasil, por meio do Decreto no 19.890 , de 18 de abril de 1931 (Capítulo III), que dispunha sobre a organização do ensino secundário, no contexto da chamada reforma Francisco Campos do ensino secundário (DALLABRIDA, 2009). Perdurou oficialmente até 1971, quando foi extinto. O decreto estabeleceu que o exame de admissão fosse composto de provas escritas, sendo uma de Português (redação e ditado) e outra de Aritmética (cálculo elementar), e de provas orais sobre elementos dessas disciplinas e mais sobre rudimentos de Geografia, História do Brasil e Ciências Naturais. A aprovação no exame dava direito a certificado de habilitação para a matrícula no $1^{\circ}$ ano ginasial, um dos documentos obrigatórios a serem apresentados no ato da matrícula. O candidato ao ingresso no primeiro ano do curso ginasial deveria também comprovar ter idade mínima de 11 anos, ser aprovado em exame e ter classificação suficiente até o limite de vagas da instituição em que se pretendia efetuar a matrícula.

${ }^{7}$ Montandon (1991) e Van Zanten e Duru-Belat (1992) já haviam advertido para a importância dos pais de famílias pouco favorecidas para o alongamento, com sucesso, dos estudos de crianças e jovens.
}

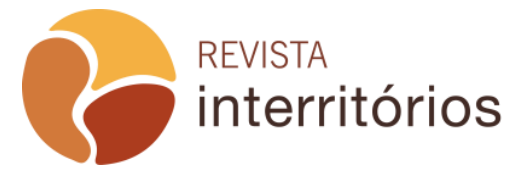


Memórias de um aluno do curso secundário: uma experiência escolar humanizadora

Zuenir Ventura disse ter sido 1968 o ano que não terminou, em razão de marcar o início dos "anos de chumbo". Pesquisadores, como Martins, sustentam que fora o ano de nascimento da "geração Al5", em referência ao Ato Institucional no 5 . O ano de 1968 marca meu ingresso no então Ginásio de Aplicação $(\mathrm{GA})^{9}$ como aluno do primeiro ano ginasial, após uma concorrida seleção ${ }^{10}$. O processo seletivo de 1967 para o ingresso em 1968 de tão rigoroso, foi realizado em duas rodadas de aplicação dos testes, porque a primeira delas não havia selecionado sequer metade das vagas em concurso. Fui selecionado, como outros dezenove meninos, na segunda rodada. Refiro-me a meninos porque o regime escolar misto ${ }^{11}$ só seria adotado para a turma ingressante no ano de 1969.

O ingresso no GA em um ano decisivo para os rumos do regime que se erigira em 1964 não passara isento e me permitiu fazer, a sangue quente, uma espécie de educação política continuada e democrática. O contexto político pósgolpe levara ao acirramento das posições, e tal acirramento expressava-se em confrontos políticos por toda parte, inclusive em escolas e universidades. Os espaços físicos das instituições educativas, em especial as do Ensino Superior, foram palco de enfrentamentos de toda sorte. As paredes dos corredores da

\footnotetext{
${ }^{8} \mathrm{~A}$ expressão ganhou notabilidade pelas mãos do sociólogo Luciano Martins, que a teria usado no ensaio Geração Al5 e Maio de 68. Duas manifestações intransitivas, publicado em 1969 e republicado em 2004, para designar jovens brasileiros que, em 1968, possuíam entre 16 e 20 anos e, portanto, teriam tido grande parte de sua formação sob uma cultura autoritária.

${ }^{9}$ Escola de ensino secundário, ofertante do curso ginasial (1 $1^{\text {a }}$ a $4^{\text {a }}$ série), criada em março de 1958, vinculada à Faculdade de Filosofia de Pernambuco (FAFIPE) da Universidade do Recife, hoje UFPE.

${ }^{10}$ Fora também um ano capital para o Ensino Superior, uma vez que é ele o marco temporal da reforma universitária promovida pela Lei $n^{\circ}$ 5.540/1968. Essa lei foi responsável pela modernização do Ensino Superior universitário no Brasil. A reforma extingue a cátedra, altera o processo seletivo para ingresso na universidade (unifica o exame vestibular), modifica a estrutura e organização das universidades, visando uma maior produtividade com uma menor destinação de recursos, cria o sistema de créditos, permitindo a matrícula por disciplina, além de prever a nomeação de profissionais de fora do quadro docente da universidade para as funções de reitor e de diretor de centro. A reforma atinge as Faculdades de Filosofia, Ciências e Letras, ao redistribuir os cursos por centros organizados por áreas do conhecimento e criar também as Faculdades ou Centros de Educação.

${ }^{11}$ Separar meninos de meninas, em escolas públicas e privadas, é uma característica da escolarização no Brasil e em muitos países do Ocidente. Em nosso país, o regime misto foi adotado em instituições públicas a partir dos anos 1960. Mas, as escolas para um único sexo (single-sex) não desapareceram. "De acordo com o Censo Escolar da Educação Básica em 2010, existem pelo menos 612 escolas públicas e privadas em regime não misto no país. Esse número contempla centros de reeducação, que são tradicionalmente não mistos, escolas técnicas e escolas religiosas, além de escolas de educação básica". Disponível em: https://www.gazetadopovo.com.br/educacao/so-para-meninos-ou-meninas-escolas-com-sexounico-voltam-a-ganhar-espaco-6ntf28dmqom2gy6q5z9yg0a6r/. Acessado em: 20/08/2019.
}

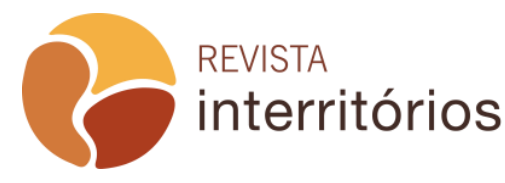


Faculdade de Filosofia de Pernambuco (FAFIPE), instituição a que estava vinculado o GA, por exemplo, pareciam naquele final dos anos 1960 páginas de "livros" nas quais se registravam passagens de lutas políticas em nível nacional e internacional contra regimes autoritários de diferentes matizes políticos. Lendo escritos e grafites naquelas paredes, tomei conhecimento de importantes acontecimentos políticos ocorridos no país e no exterior.

No GA e na FAFIPE, educava-se pela/para a resistência, forjavam-se espíritos democráticos no cotidiano da luta e da ajuda mútua e silenciosa. Pequenos grandes homens e mulheres anônimos/as ajudavam a tecer a rede de solidariedade sem a qual muitos mais teriam sucumbido. Tempos difíceis, tempos solidários.

Pergunto-me, até hoje, quanta energia os educadores do GA despendiam para garantir uma experiência em que grassava a liberdade de expressão, fomentava-se a crítica, estimulava-se o diálogo, a criatividade e a convivência respeitosa entre diferentes. Portanto, uma educação humanizadora na melhor tradição freireana, ainda que fosse uma escola de orientação pedagógica claramente escolanovista, denotada pela máxima deweyneana tantas vezes repetida pela direção, pela orientação educacional e pela coordenação pedagógica do GA: "educar para e pela vida"12. Em definitivo, uma escola impregnada do pensamento de John Dewey (1859-1952), segundo o qual a educação se centraria no desenvolvimento da capacidade de raciocínio e do espírito crítico do aluno. Por tais razões, a experiência escolar no GA propiciava um corte pedagógico com o que vivera na escola primária, descortinando para mim uma nova mirada sobre a formação humana.

Foram sete anos vividos, sete anos muito bem vividos, nos quais cursei 0 ginásio e o científico, etapas do ensino secundário ${ }^{13}$, conforme a nomenclatura anterior às Leis no 5.692/71 e oㅜ 9.394/96. Ali, firmei as bases de minha formação cidadã, exposta à prática de uma educação desafiadora e estimuladora da curiosidade epistêmica, da experimentação de relações entre educador e educando permeadas pelo respeito mútuo e pela criticidade, mas, sobretudo, generosa na relação com o saber sobre si, sobre o Outro e sobre o mundo. Por meio das metodologias ativas, fui lançado ainda a novas aprendizagens quanto

\footnotetext{
${ }^{12}$ A educação deve servir para resolver situações da vida, e a ação educativa tem como elemento fundamental o aperfeiçoamento das relações sociais, defendia Dewey.

${ }^{13}$ O ensino secundário, vigente nos anos 1960 e até 1971, resultou, segundo Dallabrida (2009), de rearranjo promovido pela Lei Orgânica do Ensino Secundário de 1942 (Reforma Capanema) na reforma Francisco Campos, datada de 1931. Ela estabeleceu o ciclo ginasial, de quatro anos, e o ciclo colegial, de três anos, divisão que permaneceu na estrutura do ensino brasileiro até o início da década de 1970, quando foi criado o $1^{\circ}$ grau, a partir de fusão do curso primário com o ciclo ginasial, e o $2^{\circ}$ grau, formado pelo ciclo colegial. Ainda segundo Dellabrida (2009, p. 187): "[...] esse novo desenho alinhava o Brasil aos países ocidentais mais desenvolvidos, que, no mínimo desde fins do século XIX, modernizaram o ensino secundário também pela criação de dois ciclos".
}

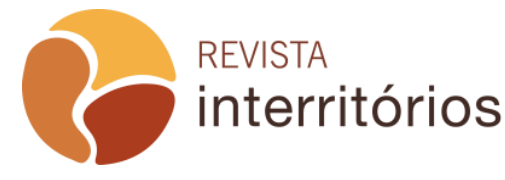


a saberes disciplinares integrados (falava-se em Ciências Sociais, Ciências Naturais) e a conteúdos humanísticos (Filosofia, Artes Plásticas e Música eram, sim, conteúdos incontornáveis). E tudo isso num tempo em que a hegemonia tecnicista já se instalara no proscênio educacional.

Em matéria de política e prática curriculares, o GA postava-se à contracorrente das políticas educacionais e diretrizes dominantes de corte técnico-científicas. Quanto a estratégias e procedimentos de ensino, pude experimentar vivências educativas nas quais a construção do conhecimento era a finalidade. Os chamados clubes, dentre os quais destaco o de Ciências e o de Imprensa, dentre outros, agrupavam alunos de diferentes séries por centros de interesse, numa versão aclimatada das ideias de Jean-Ovide Decroly ${ }^{14}$ (18711932). No Clube de Imprensa, pude publicar minha primeira matéria. Uma tosca e ingênua entrevista com um estudante do Ginásio sobre temas esportivos. Essa primeira experiência em minha trajetória de constituição como leitor e escritor, insere-se em um percurso que me levou, já com mais idade e junto com outros colegas, à redação de jornais escolares, um primeiro no formato mural e outro impresso por mimeógrafo a óleo, este denominado Zeros à Esquerda, nos quais expressei/expressávamos meus/nossos entendimentos e interesses culturais, políticos e filosóficos. Sob a influência da imprensa "nanica", ousávamos buscar inspiração em O Pasquim, Opinião, Movimento, Em Tempo e outros "nanicos" do jornalismo de resistência que se praticava no país. Urge registrar os efeitos da prática pedagógica de uma docente de Língua e Literatura, Myrtha Carvalho, a quem seremos gratos pelo gosto pela leitura e pela escrita que formou em nós, seus/suas alunos/as.

Um ano após meu ingresso, o GA conheceu uma dupla mudança. Tornouse uma escola mista, ao incorporar meninas ao seu alunado, e transformou-se em Colégio de Aplicação (CAp), passando a ofertar turmas do científico (segundo ciclo do curso secundário, na nomenclatura das reformas educacionais brasileiras do pós II Grande Guerra, explicitada na nota 14). A chegada das meninas criou um novo cenário e ambiente de convivência, onde se paquerava e se namorava, mas, sobretudo, onde não se podiam mais circular livremente as revistinhas suecas, introduzidas por colegas cujos irmãos mais velhos eram fornecedores, como também os desenhos eróticos de Carlos Zéfiro ${ }^{15}$, adquiridos

\footnotetext{
${ }^{14}$ Decroly, médico belga dedicado ao estudo da evolução física e mental de crianças deficientes mentais, sustentava que as aprendizagens ocorreriam de maneira espontânea pelo contato da criança com o meio, campo de estimulação e de interpelação do real por meio de perguntas. Postulava o interesse como pressuposto básico para a aprendizagem. Para ele, esse estado desperto da criança estaria na base de toda atividade, devendo a educação incitála a observar, associar, expressar o mundo.

${ }^{15}$ Carlos Zéfiro é o pseudônimo do funcionário público Alcides Aguiar Caminha. Zéfiro ilustrou e publicou, durante as décadas de 1950 a 1970, histórias em quadrinhos de cunho erótico que ficaram conhecidas por "catecismos". Nossos espíritos juvenis foram, seguramente, forjados por esses preceitos.
}

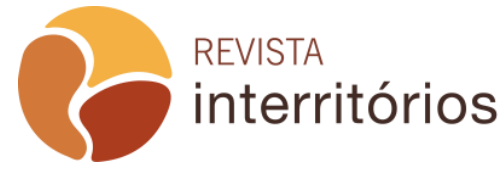


clandestinamente na banca de revista situada na calçada da Igreja da Soledade, ao lado do convento das Dorotéias ${ }^{16}$, um santo altar de "rezas" semanais dos que faziam a volta à casa, através de transporte público, tomado na Av. Conde da Boa Vista, logo depois experimentarem alumbramentos juvenis.

Durante um certo tempo, as turmas mistas foram formadas por repartição igualitária de gênero - quinze meninos e quinze meninas. A igualdade expressava, naquele momento, um modo de entendimento firmado, pelo CAp, sobre as questões de gênero na sociedade. Ela teve seus rebatimentos sobre a composição do corpo discente das escolas, sendo, contudo, questionada, mais tarde, pelo Ministério Público Federal, que, em respeito à isonomia constitucional, orientou o CAp, por meio de Termo de Ajustamento de Conduta, a não fixar qualquer reserva de vagas por gênero, deixando ao processo seletivo a definição da composição das novas turmas selecionadas. Curiosamente, aplicado o Termo de Ajustamento, os quantitativos por gênero têm mantido um relativo equilíbrio, denotando que as capacidades, os conhecimentos, as competências, as habilidades, o desempenho não são atributos exclusivos ou prioritários deste ou daquele gênero.

Para conduzir práticas curriculares inovadoras e ousadas para a época, o GA/CAp dispunha de um professorado muito qualificado. A primeira geração desses docentes, por assim dizer, era composta por uma combinação entre jovens e experientes professores, com título de curso de graduação em suas áreas de atuação, em geral bacharelados. Despontavam nomes como os de Maria Antônia Amazonas McDowell, Dulce Campos, Maria das Graças Rabêlo, José Lourenço de Lima, Clifford Erickson, Edson Bandeira de Melo, Myrtha Carvalho, Jerônimo Freitas, Benedito Furtado, Augusto Burle, entre tantos

\footnotetext{
${ }^{16}$ Dorotéias é uma congregação de irmãs vindas de Portugal no século XIX, dedicadas à Educação Básica e Superior em nosso país, que firmara, em 1946, acordo de "Agregação" com a então Universidade do Recife para que ela pudesse se constituir como tal. A Lei que cria as Universidades naquele ano obrigava a instituição universitária possuir uma Faculdade de Filosofia, Ciências e Letras, portanto uma unidade acadêmica que se desincumbisse da formação de professores para os cursos primário e secundário (ginasial, colegial). As Dorotéias haviam criado, em 1941, a FAFIRE e, por força da Agregação (acordo de cooperação que firmam duas instituições, nesse caso, uma pública federal e outra privada confessional), passou a funcionar em convênio com a UR, respondendo pelos cursos de bacharelado em Filosofia, Letras Neolatinas e Anglo-germânicas, Geografia e História, História Natural, Ciências Sociais e Pedagogia e as licenciaturas (Curso de Didática), além de um curso superior de Doutrina e Moral Católica, em três anos. Só em 1951 é que a UR passou a ter sua própria unidade, denominada Faculdade de Filosofia de Pernambuco, que resultou da federalização de Faculdade criada pelo ex-governador de Pernambuco Barbosa Lima. Antes de funcionar no seu conhecido prédio da rua Nunes Machado, ela foi instalada em uma escola estadual, o Grupo Escolar Frei Caneca, com sede no bairro da Soledade. A FAFIPE havia recebido autorização para o funcionamento dos cursos de Filosofia, Matemática, Letras Clássicas, Letras Neolatinas e Pedagogia (Decreto no 28.092, de 08/05/1950) e dos cursos de Letras Anglo-germânicas e Geografia e História (Decreto no 28.266, de 16/06/1950).
}

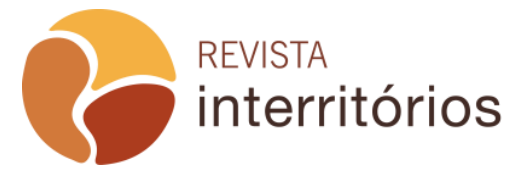


outros $^{17}$. Em sua maioria, esses docentes integraram, também, o corpo docente da antiga Faculdade de Filosofia de Pernambuco da Universidade do Recife, de outras instituições de Ensino Superior (IES) e de importantes escolas da Educação Básica. A segunda geração do GA/CAp, no entanto, era composta de professores com um perfil mais ajustado às novas tarefas atribuídas à universidade pública pela Reforma Universitária de 1968. Embora tenha sido recrutada na condição de graduados, a quase totalidade da nova geração buscou cursos de mestrado e doutorado em sua área de especialização, estimulados pelo clima de incentivo e pelo apoio conferidos pelo plano de cargos e carreira institucional. Muitos migraram, depois de larga experiência na Educação Básica, para o Ensino Superior, em nível de graduação e pósgraduação lato e stricto sensu. Sem querer ser exaustivo, lembro os nomes de Socorro Ferraz, Antonio Montenegro, Idalina Pires, Marcos Tavares, Marcelo Tavares, Ernani Campos, Marcelo Câmara, Sérgio Ramos, Kátia Barreto, Marcos Honorato, entre outros.

Antes de se transferir para as novas instalações no campus da Cidade Universitária, o CAp foi uma escola de recursos materiais pouco adequados ao público infantojuvenil e juvenil que a frequentava. Os prédios sede, em seu endereço tradicional da Rua Nunes Machado, 42, na Boa Vista, possuíam salas amplas, algumas das quais já organizadas como salas especializadas, por área do saber. Assim eram as salas de Artes Plásticas, de Música e de Ciências Naturais.

Foto 3: Antigo prédio da FAFIPE/FE-UR, bairro da Soledade, Recife

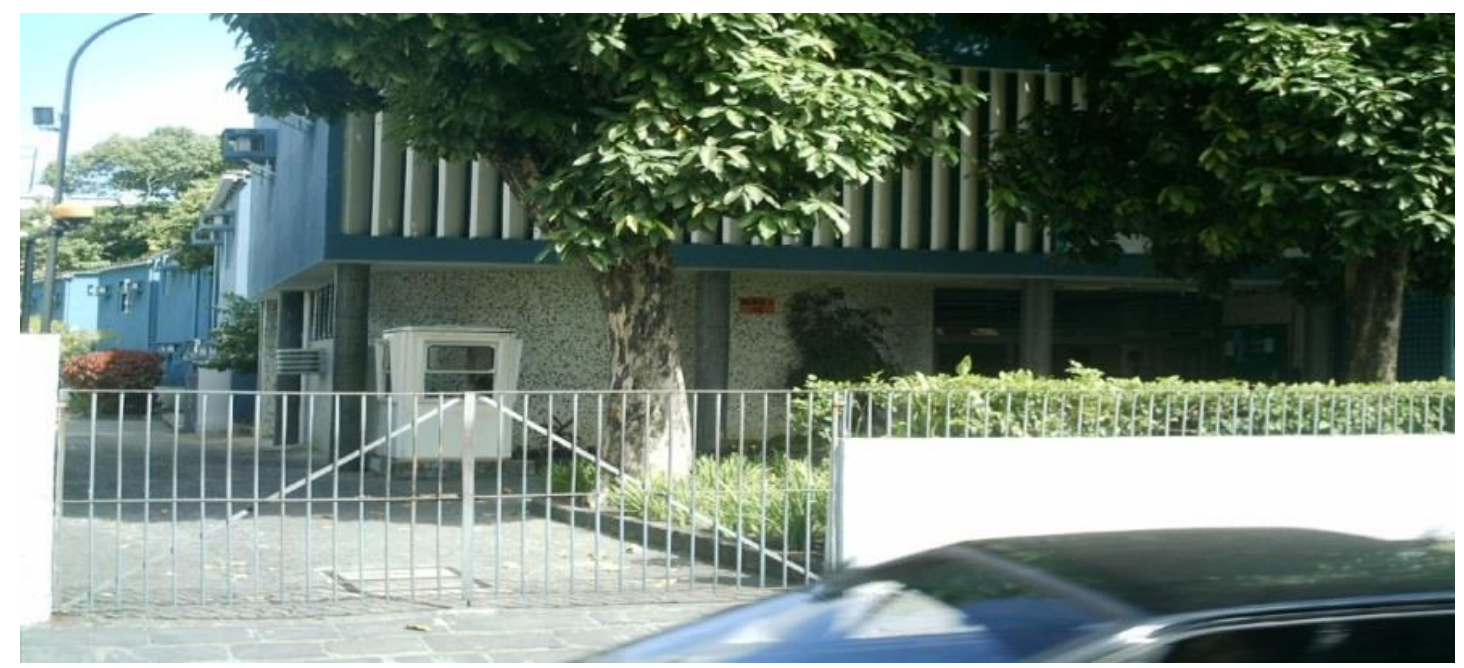

Fonte: Foto do autor

${ }^{17}$ Não cabe ao escopo deste texto nomear todos os professores. Sei que me esqueci de muitos e já apresento minhas desculpas.

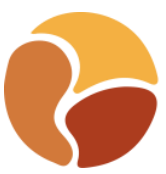

Interritórios | Revista de Educação

Universidade Federal de Pernambuco, Caruaru, BRASIL | V.5 N.9 [2019] 
No entanto, nenhum equipamento existia para que práticas esportivas e de educação física pudessem ser realizadas. Até mesmo as atividades recreativas se faziam em espaços improvisados e mal adaptados. Contávamos com um pátio interno, todo revestido em pedras paralelepípedos, que ferviam os pés de alunos nas "peladas" jogadas sob sol inclemente. Traves em madeira para a prática do espiribol foram instaladas em um terreno rico em humos cuja terra negra emporcalhava sapatos e meias brancas do uniforme. A cantina escolar só foi instalada em 1970: a cantina da "Vovó", assim a batizamos, em referência à idade de uma de suas gestoras.

\section{FOTO 4: Pátio interno da FAFIPE/FE-UR}

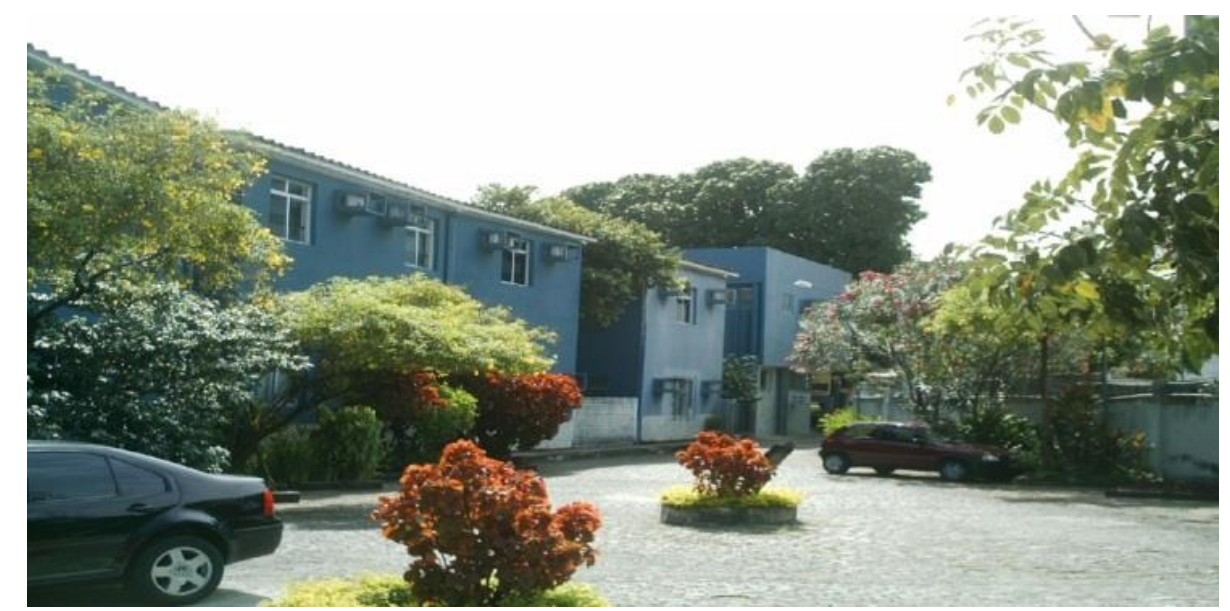

Fonte: Foto do autor

Para que não se insinue que advogo uma perspectiva idealizada do GA/CAp, por realçar seus êxitos pedagógicos, constato e expresso um certo número de contradições que permeavam a escola e sua prática pedagógica. Sabíamos, e era visível um embate interno, intenso, mas respeitoso, entre professores/as "disciplinadores/as" e aqueles/as estimuladores/as de uma relação docente-discente mais aberta, onde o questionamento e a crítica eram desejados, estimulados e praticados. Essa divisão não imaginária e imaginada era comentada nos corredores, nas salas de professores e da coordenação pedagógica. Sabia-se das clivagens internas, e elas pareciam ser transparentes e bem suportadas. Curioso observar que os tidos como "disciplinadores", quando se viam diante de uma crítica, não de um membro da comunidade interna, mas de pessoa externa à escola, logo se postavam em defesa dos ideais pedagógicos e, pasmem!, com o uso de argumentos contra os quais se debatiam e criticavam nas disputas internas. A escola alimentava-se dessa continuada discussão, que deixava à vista a existência de variados caminhos para a construção de sua prática educativa. Definitivamente, o GA/CAp não era um lugar educativo para o caminho único.

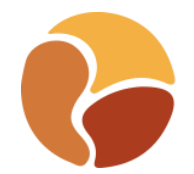

Interritórios | Revista de Educação

Universidade Federal de Pernambuco, Caruaru, BRASIL | V.5 N.9 [2019] 
Críticas, aliás, não faltavam ao que era e ao que conseguia ser, e até ao que não era e nunca foi. Críticas que se estenderam no tempo, uma vez que os grupos sociais que a vocalizavam permanecem ativos até os dias atuais. $O$ GA/CAp sempre foi acusado de ser elitista, de ser uma escola para uma elite econômica e intelectual. Mais econômica que intelectual. A narrativa era de que não havia em seu corpo discente alunos pobres e oriundos de escolas públicas. Portanto, por ser uma escola pública federal, estava fora da realidade. $\mathrm{Na}$ verdade, padecem de esquizofrenia ideológica os porta-vozes desse argumento. Por trás dele esconde-se um desejo inconfesso: uma escola pública não pode ser de qualidade. Portanto, desconfio que é portador de crença privatista e privatizante quem veicula tal ideia, sobretudo quando se refere aos resultados obtidos pelo GA/CAp ao longo do tempo. E não faltam exemplos de que o GA/CAp foi e é o lugar do êxito dos improváveis. Exemplos de alunos de origem popular que sequer possuíam recursos para adquirir todo o uniforme - para os quais, e numa ação de natureza inclusiva, se faziam rifas, cujos sorteios já tinham o prêmio carimbado - e que conheceram o caminho do êxito, alcançando níveis de escolaridade muito acima da média regional e até de estratos sociais favorecidos. Havia também aqueles que recebiam apoio de professores de Língua Francesa da escola, franceses residentes no Recife, que os levavam a estudar, com bolsas integrais, língua estrangeira na Alliance Française. Aqueles que nunca chegaram à escola em automóveis da família, mas precisavam tomar um ou dois transportes públicos desde seus bairros periféricos. $E$, mais recentemente, os beneficiários da lei das cotas sociais e étnico-raciais. Esses argumentos se calam, porque a existência de um GA/CAp deixa a nu seu conteúdo preconceituoso, seu gosto pela segregação, seu elitismo deslavado.

O CAp esteve sediado, entre 1958 e 1975, à rua Nunes Machado, no 42, em pleno bairro da Boa Vista, na região do centro da cidade. A Boa Vista era, entre o final dos anos 1960 e o início dos anos 1970, um bairro em transformação. Mantinha ainda muitas residências, uma universidade confessional em expansão, grandes colégios, alguns dos quais destacados estabelecimentos de ensino confessionais - o Nóbrega, dos jesuítas; o Marista, da irmandade do mesmo nome; o São José, da congregação das Dorotéias; o Salesiano e o Maria Auxiliadora, da congregação salesiana; mas também escolas leigas, a exemplo do Padre Felix, do Eucarístico e muitos colégios originários de "cursinhos" preparatórios ao vestibular, tais como, o União, o Radier, o 2001, o Esuda, estabelecimentos onde medrava uma cintilante educação utilitária, instrumental e mercadológica. Mas o charme do bairro era a presença da fábrica de refrigerantes Fratelli Vita, instalada em imponente 
casarão no largo da Soledade ${ }^{18}$. Havia também restaurantes conhecidos e frequentados por famílias (Casa d'Itália, Recanto Gaúcho) e boêmios recifenses (Cantina Star), próximos ao antigo Nosso Teatro, hoje Waldemar de Oliveira, na praça Oswaldo Cruz.

Mas era, sobretudo, o bairro da Universidade do Recife (UR). A Reitoria, na rua do Hospício, em frente ao Parque 13 de Maio; a Faculdade de Direito do Recife (FDR) na praça Adolfo Cirne; a Escola de Engenharia de Pernambuco (EEP) e a Escola de Geologia de Pernambuco, na rua do Hospício; a Faculdade de Arquitetura, na Conde da Boa Vista; e o Serviço de Extensão Cultural, criado no reitorado João Alfredo e coordenado por Paulo Freire, instalado na rua Gervásio Pires. O Bairro do Derby, vizinho, abrigava a Faculdade de Medicina do Recife, na rua Amaury de Medeiros; a Escola de Belas Artes de Pernambuco e a Escola de Farmácia, na rua Benfica.

FOTO 5: Construção do CE/UFPE, 1974

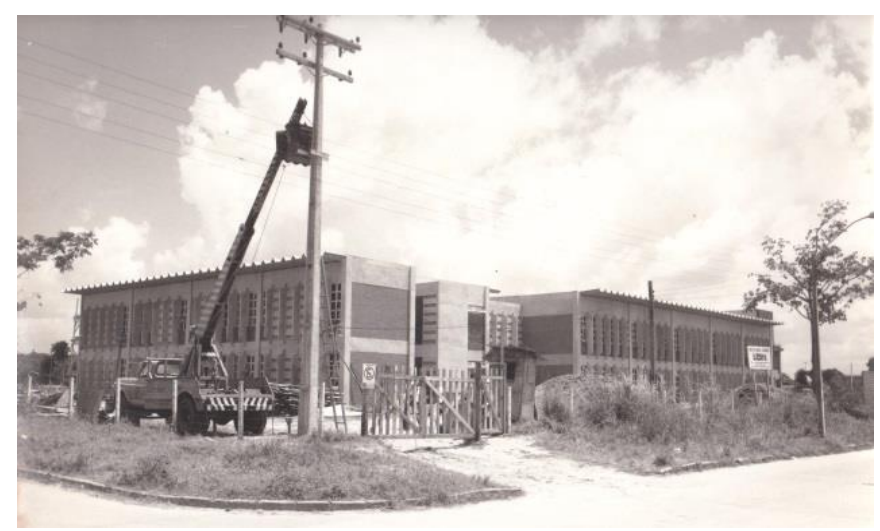

Fonte: Acervo ASCOM/UFPE.

Cedo da manhã, como logo após o meio-dia, essa área do bairro no entorno do GA/CAp fervilhava de uma população jovem, no entra-e-sai das escolas, nas passagens de turno. Essas ruas assistiram às tantas manifestações estudantis organizadas ao longo dos anos 1960 contra o regime militar, nas quais secundaristas e universitários travavam confrontos com agentes dos órgãos de segurança do Estado. Como se viu, muitas das faculdades, institutos e escolas do Ensino Superior e a Reitoria da Universidade do Recife ainda estavam sediadas no centro do Recife, antes de se transferirem para o campus da Cidade Universitária ${ }^{19}$, para que ficassem distantes das pessoas e do comércio, e a população universitária confinada e "exilada".

${ }^{18}$ Criada pelos irmãos José e Francisco Vita, migrantes italianos. Antes de instalar-se na Soledade, em edificação que abrigara insurretos da Revolução Praieira, esteve sediada à rua da Imperatriz.

${ }^{19}$ Pesquisa de Renata Cabral (2003) desvelou como ocorreu a ocupação das terras destinadas à construção da cidade universitária, no antigo Engenho do Meio. A ocupação dessas terras

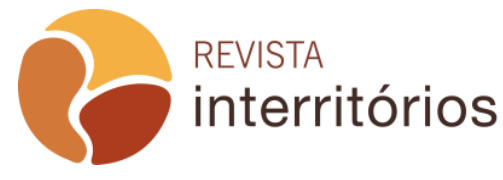




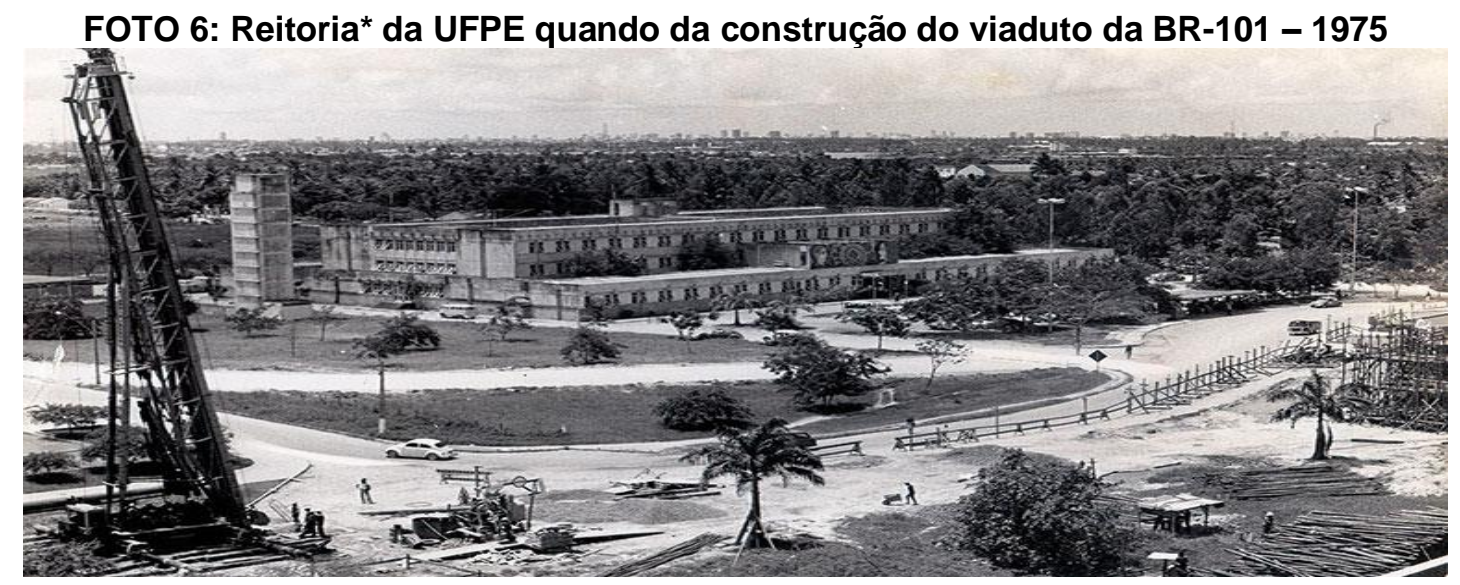

Fonte: Incampus, no 207, ago. 2016. *A construção do prédio da Reitoria da UFPE data de 1970.

Diversas aprendizagens foram fomentadas pela a exposição a que estávamos submetidos nas aulas de Filosofia, Literatura e Artes Plásticas. O estudo do modernismo e do seu ato fundador na cultura brasileira, a Semana de Arte Moderna de 1922, desencadeou uma iniciativa por parte dos alunos de diversas turmas, iniciativa amplamente apoiada pelos professores ${ }^{20}$, coordenação e direção da escola, de organizar, à semelhança, uma Semana de Artes. As duas edições das quais participei contaram com uma programação de três dias, à semelhança daquela em que se inspirara, toda ela com produções do alunado e de professores orientadores. No primeiro dia, fez-se a apresentação de músicas, seguida, no segundo dia, de recital de poesias e prosas para, no terceiro dia, ter-se a encenação de uma peça de teatro. A primeira edição teve lugar no Salão Nobre da FAFIPE e a segunda em auditório do Centro Social da Soledade, situado na parte posterior da Igreja Nossa Senhora da Soledade, na Boa Vista.

\footnotetext{
"[...] remonta pelo menos ao século XVII, tendo Pereira da Costa registrado que esse engenho, confiscado pelos holandeses, foi por eles vendidos a Jacob Estacour e a João Fernandes Vieira, um dos articuladores da Restauração Pernambucana, e que, em 1686, pertencia à viúva de Vieira. O engenho transforma-se na Usina Meio da Várzea, em 1904, e funciona até 1937. Alguns anos depois, em 1946, as terras são parceladas e passam a constituir o Parque Residencial do Engenho do Meio da Várzea, cujos lotes seriam adquiridos em grande parte, já em 1948, um ano antes da chegada de Russo, pela Universidade do Recife" (p. 35).

${ }^{20} \mathrm{Na}$ leva dos apoiadores, esteve a professora Myrtha Carvalho, mestra de tantos incentivos em suas sempre criativas aulas de Língua e Literatura. Veio também o professor de Matemática, Hélcio Matos, se juntar na condição de "diretor" de peça de Dias Gomes, O Santo Inquérito, montada para a I Semana, datada de 1973. A presença de um professor de Matemática, em razão da imagem que goza essa disciplina entre os alunos da Educação Básica, era a nota singular, e de causar surpresa. Anos depois soubemos que ele tinha desempenhado o primeiro papel de um Jesus negro em auto da Semana Santa encenado no Brasil, cuja montagem teve a assinatura de Isaac Gondim, professor de Prática de Ensino em Artes Cênicas da UFPE.
}

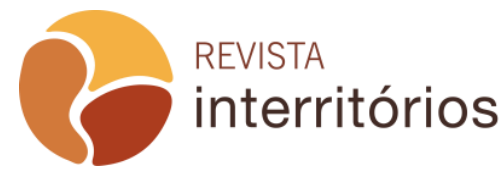


Foram sete anos de uma experiência inicial muito bem vivida. Essa experiência logo se enriqueceu de outras tantas. Estudante do curso de Licenciatura em História, vim cumprir o estágio curricular obrigatório no CAp. Concluído o curso, prestei concurso para Professor Auxiliar de Prática de Ensino de Ciências Sociais do Departamento de Métodos e Técnicas de Ensino, do Centro de Educação ${ }^{21}$, em 1979. Ato contínuo, os estagiários sob minha responsabilidade passaram a cumprir seus estágios nas turmas do CAp.

\section{Síntese da trajetória escolar do formador de professores}

Cursei a Educação Básica de forma contínua, sem conhecer fracasso escolar, ainda que fosse um estudante de desempenho meramente mediano. Nunca fui alvo de prêmios e de homenagens, salvo quando me destaquei na quarta série primária e obtive, por isso, o reconhecimento da professora responsável pela turma, bem como, quando da conclusão do ginasial, ocasião em que o Serviço de Orientação Educacional do CAp me distinguiu por atitude face a um problema disciplinar ocorrido em sala, envolvendo três estudantes e um professor de Matemática. Uma trajetória escolar sem percalços, mas também sem maiores brilhos, me fez um estudante "disciplinado", embora inquieto, indagador e crítico. Se a escola primária teve o condão de me preparar para a forma escolar, conferindo-me um ensino dirigido à assimilação de conhecimentos sistematizados, organizados em disciplinas (LIBÂNEO, 2009), a escola secundária contribuiu para o despertar da consciência crítica, para o exercício competente da fala, para o gosto pela leitura e para a expressão escrita lógica, correta e articulada. O valor da escola e de seus professores estava inscrito em mim, evidenciando a presença de uma instituição tantas vezes estigmatizada por incorporar projetos e valores socialmente hegemônicos e agir em favor da reprodução social. Vi, de dentro, o exercício da resistência cultural e a formação cidadã engendrarem resultados formativos edificantes, e não só em mim, mas em um grupo de jovens que se preparavam para um nível educacional superior, no qual obteriam sua formação profissional e para a vida. Tenho certo que a passagem pelo GA/CAp foi decisiva para a escolha profissional que fiz em meados dos anos 1970.

Na escola primária, conheci só professoras (feminização e feminilização do métier, como indicou Maria do Carmo Gonçalo Santos, 2004), todas diplomadas pela Escola Normal. Um nível de formação compatível com as exigências dos anos 1960. Lembro que só mais tarde as exigências se elevaram,

\footnotetext{
${ }^{21}$ A FAFIPE se transformou em Faculdade de Educação em meados dos anos 1960, e esta, em 1975, ao transferir-se para o campus universitário, no Engenho do Meio, adotou o nome de Centro de Educação (CE), desta feita por força das determinações da Reforma Universitária no âmbito da UFPE.
}

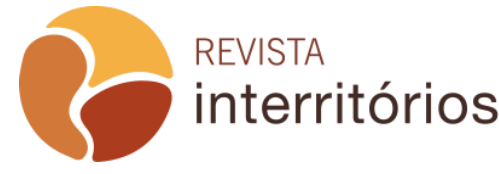


com a edição da LDB no 9.394/96. Saviani (2017) chama atenção para o que dispõe o parágrafo $4^{\circ}$ do Art. $87^{22}$ das Disposições Transitórias da LDB vigente, in verbis: "Até o final da década da Educação somente serão admitidos professores habilitados em nível superior ou formados em treinamento em serviço". Insere ainda tal dispositivo legal em perspectiva histórica. Salienta o papel inaugural das Escolas Normais, criadas desde a Revolução Francesa (1789-1795) enquanto instituições sociais a quem se atribuía o encargo de formar professores para a escola primária. Destaca que o Brasil, seguindo tendência europeia, inicia, com a edição do Ato Adicional (1834), ainda sob o Império, a implantação das escolas normais sob a responsabilidade das províncias, a primeira tendo sido instalada em Niterói, em 1835, inaugurando o envolvimento do Estado brasileiro com a formação do professor. "A consolidação das escolas normais no Brasil resultou de um longo, difícil e oscilante processo que só veio a atingir seu ponto de maturação nos anos 50 e 60 do século XX", atesta Saviani (2017, p. 8). É justo nos anos 1960 que se cruzam minha história escolar em nível primário com a de minhas professoras, formadas, seguramente, na segunda metade dos anos 1950. Sou, por conseguinte, parte de uma história que envolve esforço de escolarização da população e da ampliação da formação de seus professores. A história das escolas normais sofrerá abrupta interrupção com a edição da LDB do regime militar, Lei no 5.692/71, a qual, por meio do Art. 30, institui as Habilitações Específicas do 20 Grau para o Exercício do Magistério de $1^{\circ} \mathrm{Grau}$, dispositivo que será responsável pela desmontagem do "sistema" das escolas normais, iniciada em 1970. Esse desmonte, que resultou no sufocamento da chamada cultura normal, no dizer de Jean-Claude Forquin, foi magistralmente analisado na tese de doutoramento de Eliete Santiago (1994).

No que concerne à minha escolarização em nível secundário, tive professores habilitados em nível superior, porém em cursos de bacharelado, em grande maioria, alguns dos quais habilitados em áreas distantes de seus campos de atuação docente, a exemplo daqueles que, formados bacharéis em Direito, ministravam cursos de Língua Portuguesa ou de História na educação secundária. Alterações na direção da obtenção da compatibilidade entre a área de formação e a do exercício da docência, ainda não dominante nos últimos anos da década de 1960, período de meu ingresso no ensino secundário, só vieram a acontecer ao longo dos anos 1980 e se completar integralmente nos anos 1990.

Cumpre revisitar o que advertiu Libâneo (2009) sobre a íntima relação entre o que escola fez com ele e a formação de seu pensamento sobre a escola. A ideia cabe bem para a narrativa que construí de minha trajetória escolar. Vejo nela os elementos experienciais que colaboraram em muito para 0 engendramento do modo como passei a conceber, mais tarde, a escola e o professor quando assumi as funções de docente, primeiramente, na educação

${ }^{22}$ Este parágrafo foi, mais tarde, revogado pela Lei oㅡ 12.796, de 04 de abril de 2013.

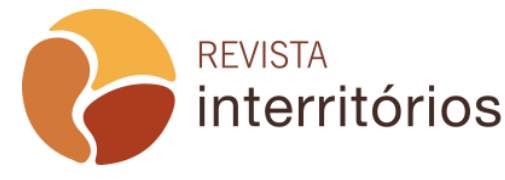


básica, e, depois, no ensino superior. Fui marcado por tais experiências que, de toda evidência, balizam os saberes docentes que construí. Assim, mais os anos se sucediam em minha tarefa de formar novos professores, mais passei a valorizar a reflexão sobre as experiências na escola, minha e dos estudantes futuros professores. Ali colhi material frutífero para a problematização e a tematização da prática docente em espaço escolar. Portanto, o texto que forneço é também um convite para que cada docente em formação ou em exercício revisite sua trajetória escolar, com vistas a restituir a si e a outros sua narrativa histórico crítica.

\section{REFERÊNCIAS}

ALVES-MAZZOTTI, Alda Judith. Relevância e aplicabilidade da pesquisa em educação. Cadernos de Pesquisa, São Paulo, no 113, jul. 2001, 39-50.

ANDRADE, Lucimary Barnabé Pedrosa. Educação Infantil: nas trilhas do direito. S. Paulo: Unesp, 2010.

ANTÓNIO, Ana Sofia. Histórias de vida: auto-representações e construção das identidades docentes. In TEODORO, António. Histórias (re)construídas. S. Paulo: Cortez, 2004, 97-119.

AKSENEN, Elisângela Zarpelon; MIGUEL, Maria Elisabeth Blanck. Desvelando os exames de admissão ao ginásio na educação paranaense. Revista HISTEDBR Online, Campinas, $\mathrm{n}^{\circ}$ 58, p. 230-243, set. 2014, p. 230-243. Disponível em: https://periodicos.sbu.unicamp.br/ojs/index.php/histedbr/article/view/8640390/7949. Acessado em: 10/03/2018.

BARBOSA, João Alexandre. Prefácio à obra de Ecléa Bosi Memória e sociedade. Lembranças de velhos. São Paulo: Cia das Letras, 2003.

BENJAMIN, Walter. O narrador. Considerações sobre a obra de Nikolai Leskov. In: Walter Benjamin. Obras escolhidas. São Paulo: Brasiliense, 1987.

BOURDIEU, P. L'illusion biographique. Actes de la recherche en Sciences Sociales, juin 1986, no 62-63, pp.69-72.

BRASIL. Censo Escolar 2016. Notas Estatísticas. Brasília: MEC/INEP, fevereiro de 2017. Disponível em: http://portal.mec.gov.br/docman/fevereiro-2017-pdf/59931-appcenso-escolar-da-educacao-basica-2016-pdf-1/file. Acessado em: 30/10/2018.

CHAUÍ, Marilena. Os trabalhos da memória. IN BOSI, Ecléa. Memória e sociedade. Lembranças de velhos. São Paulo: Cia das Letras, 2003.

DALLABRIDA, Norberto. A reforma Francisco Campos e a modernização nacionalizada do ensino secundário. Educação, Porto Alegre, v. 32, n. 2, p. 185-191, maio/ago. 2009.

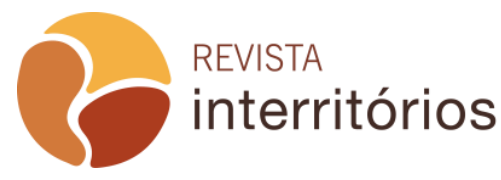


DE GAULEJAC, Vincent. L'histoire de vie ou le temps recomposé. Paris : Sociétés. Revue de Sciences Humaines et Sociales, n 18, mai 1988, p. 5-7.

FREIRE, Paulo. Pedagogia do Oprimido. São Paulo: Paz e Terra, 1983.

GATTI, Bernadete. Retrospectiva da pesquisa em educação no Brasil. Revista Brasileira de Estudos Pedagógicos, Brasília, vol. 68, nº 159, maio-agosto 1987, p. 279-288.

JACOTT, Liliana e CARRETERO, Mario. História e relato. CARRETERO, Mario. Construir e ensinar as Ciências Sociais e a História. Porto Alegre: Artes Médicas, 1998.

LIBÂNEO, José Carlos. A escola com que sonhamos é aquela que assegura a todos a formação cultural e científica para a vida pessoal, profissional e cidadã. IN COSTA, Marisa Vorraber (org.). A escola tem futuro? Rio de Janeiro: Lamparina, 2009.

LIMA, A. J. A.; SILVA JUNIOR, R. Panorama da educação brasileira na década de 1960. Anais do III Congresso Nacional de Educação (Conedu). Natal-RN, 2016. Disponível em:

https://editorarealize.com.br/revistas/conedu/trabalhos/TRABALHO_EV056_MD1_SA1 IID2286_14082016222320.pdf. Acessado em: 30/01/ 2018.

MONTANDON, Cléopâtre. Les relations entre les familles e l'école. De quelques effets sur l'identité des enseignants. Actes des Journées Scientifiques du Comité de Recherche "Modes et Proces de Socialisation". Paris: Université René Descrtes Paris V (UFR de Sciences de l'Éducation)/CNRS, 1991.

MONTENEGRO, Antonio Torres. História e memória. Recife: Jornal do Commércio. 15 de maio de 2018.

RÖWER, Basílio. Como tudo começou. Páginas da História Franciscana no Brasil. Petrópolis: Vozes, 1941. Disponível em: www.franciscanos.org.br. Acessado em: 15/03/2018.

SANTIAGO, Eliete. Les politiques de formation et de recrutement des instituteurs et les conditions d'exercice du metier dans l'etat du Pernambouc (Bresil), 1994. Tese (Doutorado em Ciências da Educação), Université Paris Descartes, Paris V, França.

SANTOS, Maria do Carmo Gonçalo. As representações sociais de gênero das professoras sobre o magistério: feminização-femilização do campo socioprofissional. 2004. Dissertação (Curso de Mestrado) - PPGE, Universidade Federal de Pernambuco, Recife.

SANTOS, Milton. O professor como um intelectual na sociedade contemporânea. Conferência de Abertura do IX Encontro Nacional de Didática e Prática De Ensino, Águas de Lindóia-SP, 4 a 8 de maio de 1998.

SAVIANI, Dermeval. Formação de professores: aspectos históricos e teóricos do problema no contexto brasileiro. Revista Brasileira de Educação. Campinas, vol. 14, no 40, jan.-abr. 2009.

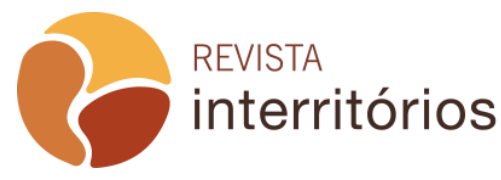


SAVIANI, Dermeval. História das ideias pedagógicas no Brasil. Campinas/SP: Autores Associados, 2011.

SAVIANI, Dermeval. Prefácio de As Escolas Normais no Brasil. Do Império à República. ARAÚJO, José Carlos Souza; FREITAS, Anamaria Gonçalves Bueno de; e LOPES, Antônio de Pádua Carvalho. Campinas: SP: Alinea Editora, 2017.

VAN ZANTEN, Agnès. e DURU-BELAT, Marie. Sociologie de l'Éducation. Paris:

PUF, 1992. 